\title{
EFFECTIVENESS OF NaOCI ALONE OR IN COMBINATION WITH EDTA ON THE DIFFUSION OF HYDROXYL IONS RELEASED BY CALCIUM HYDROXIDE PASTE
}

\author{
EFETIVIDADE DO HIPOCLORITO DE SÓDIO USADO ISOLADAMENTE OU EM \\ ASSOCIAÇÃO COM O EDTA SOBRE A DIFUSÃO DE ÍONS HIDROXILA LIBERADOS DE \\ PASTA DE HIDRÓXIDO DE CÁLCIO
}

Mara Cristina Santos FELIPPE ${ }^{1}$, Wilson Tadeu FELIPPE ${ }^{1}$, Catherine Schmitz ESPEZIM², Sérgio Fernando Torres de FREITAS ${ }^{3}$

\begin{abstract}
1- DDS, MSc, PhD, Associate Professor, Department of Stomatology, Federal University of Santa Catarina.
2- DDS, MSc, Graduate student, Department of Stomatology, Federal University of Santa Catarina.

3- DDS, MSc, PhD Associate Professor, Department of Public Healthy, Federal University of Santa Catarina.

Corresponding address: Mara Cristina Santos Felippe - Presidente Coutinho, 179/ Apto. 702 - Centro - Florianópolis

Cep.: 88.015-230 - SC - Brasil - Phone/Fax: 48 3224-1647 - e-mail: mcsfelippe@hotmail.com
\end{abstract}

Received: July 14, 2004 - Modification: October 20, 2005 - Accepted: November 11, 2005

\begin{abstract}
A

im: To evaluate the effect of different irrigant solutions employed during removal and replacement of calcium hydroxide paste on the diffusion of hydroxyl ions through root canal dentine in vitro. Methodology: Thirty-five maxillary and mandibular human canines with straight and fully developed roots were used. After mechanical preparation up to $1 \mathrm{~mm}$ short of tooth length, 30 canals were filled with calcium hydroxide paste and 5 canals were left empty; all teeth had their coronal accesses properly sealed. Teeth were placed in plastic containers with distilled water, and $\mathrm{pH}$ was read after 30 days when the paste from 20 teeth was renewed. After removal of the paste by endodontic instrumentation and irrigation with distilled water, canals were replenished with newly mixed paste in Group 1 and 2 . In these groups, final irrigation was conducted with $5 \mathrm{~mL}$ of EDTA followed by $5 \mathrm{~mL}$ of $\mathrm{NaOCl}$ in specimens in Group 1 , and $5 \mathrm{~mL}$ of $\mathrm{NaOCl}$ only in specimens in Group 2. In 10 teeth the paste was not replenished at 30 days (Group 3). All specimens were returned to the containers with fresh distilled water, and the $\mathrm{pH}$ was recorded after another 30 days. The differences between the first (30d) and second (60d) pH readings were calculated and submitted to analysis of variance and individual comparisons using the Scheffeé's test. Results: Results of mean analysis on differences of $\mathrm{pH}$ readings showed that greater diffusion had occurred on specimens in Group 3. Individual comparisons using Scheffeé’s test showed statistical significance between Groups 2 and 3, and equivalence between all other groups. Conclusion: It was concluded that the use of EDTA did not enhance diffusion of hydroxyl ions through root canal dentine.

Uniterms: Calcium hydroxide, diffusion; EDTA; Hydroxyl ions; Irrigants; Sodium hypochlorite.
\end{abstract}

\footnotetext{
RESUMO

O

bjetivo: O objetivo desta pesquisa foi comparar o efeito de diferentes irrigantes, usados durante a troca da pasta de hidróxido de cálcio, sobre a difusão de íons hidroxila. Metodologia: Foram empregados 35 caninos humanos, com canais retos e raízes totalmente formadas. Efetuado o preparo mecânico até $1 \mathrm{~mm}$ aquém do comprimento do dente, 30 canais foram preenchidos com pasta de hidróxido de cálcio e 5 permaneceram vazios (controle). Após o selamento, os dentes foram colocados em frascos plásticos contendo água destilada. Passados 30 dias, o pH da água foi medido e a pasta de 20 dentes foi renovada. Depois de removê-la com água destilada e instrumentos endodônticos e, antes de repô-la, foi feita uma irrigação com $5 \mathrm{ml}$ de EDTA seguida de $5 \mathrm{ml}$ de $\mathrm{NaOCl}$ (Grupo 1) ou somente com $5 \mathrm{ml}$ de $\mathrm{NaOCl}$ (Grupo 2). Em 10 dentes, a pasta não foi renovada (Grupo 3). Os dentes foram repostos em seus frascos com nova água destilada e, após 30 dias, o pH foi novamente registrado. As diferenças nas medidas de $\mathrm{pH}$, realizadas aos 30 e 60 dias, foram calculadas e submetidas à análise de variância e a comparações individuais pelo teste de Scheffeé. Resultados: A análise das diferenças mostrou que a difusão foi maior nos dentes do Grupo 3. Comparações individuais usando o teste de Scheffeé mostraram significância estatística entre os Grupos 2 e 3 e equivalência entre todos os outros grupos. Conclusão: O uso do EDTA não aumentou a difusão de íons hidroxila através da dentina radicular. Unitermos: Hidróxido de cálcio, difusão; EDTA; Íons hidroxila; Soluções irrigadoras; Hipoclorito de sódio.
} 


\section{INTRODUCTION}

Calcium hydroxide $(\mathrm{CH})$ has been used in endodontic therapy since Hermann ${ }^{8}$ recommended its application in dentistry as a material for pulp capping. It is commonly used as an intracanal medicament because of its antiseptic action $^{1,17}$ and its capacity to stimulate and create favorable conditions for tissue repair ${ }^{1,15}$.

In the presence of water, $\mathrm{CH}$ dissociates into hydroxyl $\left(\mathrm{OH}^{-}\right)$and calcium $\left(\mathrm{Ca}^{2+}\right)$ ions, which are responsible for its therapeutic activity. Diffusion of $\mathrm{OH}^{-}$ions raises the $\mathrm{pH}^{11,20}$ causing destruction of bacteria, inactivation of their enzymes, reduction of osteoclastic activity, and activation of alkaline phosphatase that is involved in tissue mineralization ${ }^{20}$.

Following canal preparation the dentinal walls become covered with a smear layer that acts as a physical barrier for $\mathrm{OH}^{-}$ion diffusion ${ }^{12}$. Various investigators have recommended the removal of this layer, to allow greater ion diffusion ${ }^{7,12,16}$ and, as a consequence, enhance its activity as intracanal disinfectant.

In some cases $\mathrm{CH}$ is used for some weeks to achieve a greater antiseptic action, as the diffusion of hydroxyl ions and consequent alkalinization of dentine do not occur immediately ${ }^{5,11,15}$. If the root canal is shaped, clean and dry, there is no need to change the dressing, because under these conditions and with proper coronal sealing the amount of $\mathrm{CH}$ placed in the canal can maintain ion dissociation for a considerable period ${ }^{1,4,5}$. Nevertheless, there are situations when replenishment of the paste is desirable, for instance if coronal sealing is compromised or lost.

It has been shown that $\mathrm{CH}$ may reduce dentine permeability because it may be transported or mechanically forced into the dentinal tubules causing its obstruction ${ }^{13}$, or through precipitation of calcium phosphate salts within the dentinal tubules ${ }^{3,5,12}$. Deardorf, et al. ${ }^{3}$ showed that additional applications of $\mathrm{CH}$ increased the amount of calcium at the root periphery but at a decreased rate, probably because of the precipitation of a calciumphosphate compound in the dentinal tubules. If it is necessary to replenish the $\mathrm{CH}$ paste, it may be beneficial to use a solution that not only removes the dressing, but also recovers the original permeability of dentine, so as to improve the diffusion of $\mathrm{OH}^{-}$ions.

Using distilled water, $15 \%$ etilenediamine tetracetic (EDTA), 5.25\% sodium hypochlorite $(\mathrm{NaOCl})$, and a combination of 5.25\% NaOCl and 15\% EDTA to irrigate root canals previously filled with $\mathrm{CH}$-glycol base (Calasept), Tatsuta, et al. ${ }^{18}$ concluded that all were effective in removing the paste. In a SEM study, Çalt and Serper ${ }^{2}$ verified that root canal irrigation with 17\% EDTA + 5\% NaOCl completely removed the $\mathrm{CH}$ dressing, allowing greater penetration of root canal sealers into the dentinal tubules. On the other hand, Lambrianidis, et al. ${ }^{10}$ observed that irrigation with saline, $3 \% \mathrm{NaOCl}$ or $3 \% \mathrm{NaOCl}+17 \%$ EDTA, in addition to endodontic instrumentation was not able to remove different $\mathrm{CH}$ preparations (Calxyl, Pulpdent paste, and pure $\mathrm{CH}$ mixed with distilled water), and areas of the dentinal surface remained covered with paste.

The objective of this study was to evaluate the effect of $\mathrm{NaOCl}$ alone or in combination with EDTA employed during removal and replacement of calcium hydroxide paste on the diffusion of hydroxyl ions through root canal dentine in vitro.

\section{MATERIALAND METHODS}

Thirty-five maxillary and mandibular human canines were used. No data regarding age, sex, or reasons for extraction were available. All selected teeth had straight and fully developed roots. Teeth were initially rinsed with tap water for 12 hours continually, and access performed in a conventional manner. The canal was irrigated with $1 \% \mathrm{NaOCl}$, and a hand stainless steal instrument was introduced until it reached the apical foramen for establishment of the working length.

Root canals were prepared using a circumferential filing technique ${ }^{9}$ with Flexofile (Dentsply, Maillefer, Ballaigues, Switzerland), using filing movements up to $1 \mathrm{~mm}$ short of the tooth length. Four instruments were employed to prepare the apical stop, larger than the one that bound first at length. The apical third of the canal was serially instrumented using further four instruments, each at $1 \mathrm{~mm}$ short of the anterior instrument. The middle and cervical thirds were enlarged using Gates-Glidden burs (Dentsply, Maillefer) to a maximum size of 5 or 6 . Between the use of each instrument or bur, and also at the end of instrumentation, the canals were irrigated with $2 \mathrm{~mL}$ of $1 \% \mathrm{NaOCl}$.

After shaping was concluded, the outer root surface was marked with a graphite pencil to guide removal of the cementum layer; which was achieved with diamond burs and periodontal curettes. The canals were then irrigated for 3 min with $5 \mathrm{~mL}$ of $17 \%$ EDTA, and also for 3 min with $5 \mathrm{~mL}$ of $1 \% \mathrm{NaOCl}$. The outer root surface was also rinsed with EDTA for 3 min. Subsequently, all canals were thoroughly irrigated with $10 \mathrm{~mL}$ of water, and teeth were immersed and kept in fresh $10 \mathrm{~mL}$ of distilled water for $24 \mathrm{~h}$.

After the $24 \mathrm{~h}$ period, all teeth and their outer surfaces were dried with paper points and sterile gauzes. The apical thirds of all roots were covered with a fast-setting adhesive (Araldite, Ciba Especialidades Químicas LTDA., Taboão da Serra, Brazil). Calcium hydroxide powder (Reagen-Qimibrás Indústrias Químicas S.A, Rio de Janeiro, Brazil) and propylene glycol (Quimidrol-Comércio, Indústria e Importação Ltda, Joinville, Brazil) were mixed until a fluid paste similar to that clinically used was achieved. Using Lentulo spiral filler, 30 canals were filled with the paste, and complete filling was verified using radiographs; when there were voids, more paste was added to obtain complete filling. In five teeth the canals were kept empty (Group 4 - control). Access cavities were sealed with Cimpat (Specialites Septodont, Saint-Maur-des-Fossés, France). After washing with distilled water, all teeth were placed in individual containers with $10 \mathrm{~mL}$ of distilled water $(\mathrm{pH}=6.5)$.

After 30 days, the $\mathrm{pH}$ of $10 \mathrm{~mL}$ of distilled water in contact 
with the teeth was recorded using a pH-meter (Model-374, Micronal, São Paulo, Brazil) previously calibrated with $\mathrm{pH}$ 7.0 and 9.0 standard solutions. Reading was performed 15 seconds after introducing the electrode into distilled water; between readings, the electrode was rinsed with distilled water and dried with absorbent paper. All 30 specimens with canals filled with the $\mathrm{CH}$ paste were then randomly divided into 3 groups $(n=10)$; the 10 teeth in each Group 1 and 2 had the paste replenished. After removing the temporary filling material, canals were irrigated with distilled water. Master apical files were used respectively for each specimen and irrigation repeated until no more $\mathrm{CH}$ paste could be visually observed extruding the canal. Specimens on Group 1 were finally irrigated with $5 \mathrm{~mL}$ of $17 \%$ EDTA and $5 \mathrm{~mL}$ of $1 \%$ $\mathrm{NaOCl}$ for $3 \mathrm{~min}$. All specimens on Group 2 were finally irrigated with $5 \mathrm{~mL}$ of $\mathrm{NaOCl}$ only, for $3 \mathrm{~min}$. After canals were dried with absorbent paper points, fresh paste was replenished with a Lentulo spiral. The $\mathrm{CH}$ paste was not replenished on specimens on Group 3. After sealing of teeth in Groups 1 and 2 with Cimpat, all teeth, including those in Groups 3 and 4, were washed with distilled water and stored in new individual containers with $10 \mathrm{~mL}$ of distilled water $(\mathrm{pH}=6.5)$. A further reading of $\mathrm{pH}$ was carried out after 30 days.

Finally, all specimens were inspected under light microscopy to ensure that the entire cementum layer had been successfully removed.

The differences in $\mathrm{pH}$ readings, taken at 30 and 60 days, were calculated and submitted to analysis of variance and individual comparisons using the Scheffeé's test.

\section{RESULTS}

Measurements of $\mathrm{pH}$ of distilled water in contact with teeth of Groups 1, 2, 3 and 4, made at 30 and 60 days, are presented on Table 1 . Table 2 shows the differences between measurements, as well as the mean of these differences for each group. These means, when submitted to analysis of variance (ANOVA - Table 2), indicated a significant difference between groups. Individual comparisons using Scheffeé's test showed statistical significance between groups 2 and 3, and equivalence between all other groups (Table 3).

Light microscope analysis showed that the technique used to remove the cementum was successful, since root cementum could not be identified on any specimen.

\section{DISCUSSION}

When used as an intracanal medicament, $\mathrm{CH}$ acts therapeutically by the diffusion of hydroxyl ions through the root canal system $(5,20)$. Despite the controversy in the literature about the need to change the medicament $(1,4,15$, 19) there is no doubt that the paste should be changed when coronal sealing is compromised and the root canal is contaminated. When considering replenishing the $\mathrm{CH}$ paste, root canal instrumentation combined with the irrigating solution to be used must attain two objectives: remove remnants of paste, and recover the original dentine permeability to allow optimal diffusion of hydroxyl ions or other intracanal disinfectants.

Since previous reports have shown that the presence of smear layer $(7,12,16)$ and root cementum $(11,20)$ might affect ion diffusion, the dentine in this study was made as permeable as possible by removal of cementum and use of $\mathrm{EDTA}+\mathrm{NaOCl}$ treatments within the canals and EDTA on the outer root surfaces.

Differences in $\mathrm{pH}$ were found among teeth, demonstrating that each specimen had a distinct intracanal diffusion capability (3). The differences found in $\mathrm{pH}$ measurements could indicate that removal of cementum was not complete. However, light microscope analysis showed that the technique applied to remove cementum was successful. Thus, if cementum was removed, one must

TABLE 1- Measurement of pH of water in contact with teeth in Groups 1, 2, 3 and 4

\begin{tabular}{|c|c|c|c|c|c|c|c|c|}
\hline & \multicolumn{2}{|c|}{ GROUP 1} & \multicolumn{2}{|c|}{ GROUP 2} & \multicolumn{2}{|c|}{ GROUP 3} & \multicolumn{2}{|c|}{ GROUP 4} \\
\hline Tooth & 30 days & 60 days & 30 days & 60 days & 30 days & 60 days & 30 days & 60 days \\
\hline 1 & 6.80 & 6.70 & 8.35 & 7.05 & 11.30 & 11.72 & 6.98 & 7.08 \\
\hline 2 & 12.07 & 11.26 & 7.18 & 6.90 & 6.83 & 7.12 & 6.92 & 7.00 \\
\hline 3 & 7.11 & 7.05 & 6.94 & 6.73 & 6.85 & 7.20 & 6.85 & 7.08 \\
\hline 4 & 9.88 & 11.25 & 7.07 & 6.84 & 6.99 & 7.34 & 6.82 & 6.95 \\
\hline 5 & 12.02 & 11.80 & 7.07 & 6.75 & 6.87 & 7.62 & 6.64 & 6.88 \\
\hline 6 & 11.65 & 11.88 & 11.83 & 11.89 & 11.65 & 11.82 & - & - \\
\hline 7 & 7.31 & 7.15 & 7.21 & 6.99 & 7.25 & 7.28 & - & - \\
\hline 8 & 11.94 & 12.04 & 6.92 & 6.90 & 7.41 & 7.55 & - & - \\
\hline 9 & 7.45 & 7.29 & 7.16 & 7.16 & 7.23 & 7.30 & - & - \\
\hline 10 & 7.03 & 7.13 & 7.08 & 6.92 & 7.14 & 7.98 & -- & -- \\
\hline
\end{tabular}


assume that differences in number, diameter and length of dentinal tubules may be responsible for differences in $\mathrm{pH}$ readings $(6,14)$. Nevertheless, the presence of lateral canals should also be considered, since they could allow greater ion diffusion. Teeth with $\mathrm{pH}$ values close to 7.0 probably reflected greater presence of secondary dentine, or dentinal tubules of smaller diameter and/or thicker root walls, resulting in less permeability. However, these factors may not be significant since differences in $\mathrm{pH}$ between 30d and 60d have been considered in our statistical analysis.

Samples of water from those teeth in the control group (Group 4) also exhibited some alteration in $\mathrm{pH}$. This may have occurred because residues of $\mathrm{NaOCl}$ solution may have diffused through the dentine, even though the canals were thoroughly irrigated and maintained in distilled water in an attempt to neutralize that solution.

When analyzing the differences in $\mathrm{pH}$ found between periods (Table 2), it was observed that some specimens in Group 1 presented less alkaline measurements at 60d than those at 30 days. However, the mean of these differences remained positive $(0.03)$. The mean was negative $(-0.27)$ in teeth in Group 2, which received only final irrigation with
$\mathrm{NaOCl}$. Statistical analysis did not indicate significant difference between Groups 1 and 2, suggesting that the exclusive use of $\mathrm{NaOCl}$ to irrigate the canal in order to remove $\mathrm{CH}$ mixed with propylene glycol should be sufficient.

Analysis of $\mathrm{pH}$ of water in contact with teeth in Group 3 suggests a different phenomenon. In the second recording, the $\mathrm{pH}$ of water for all samples was higher, and the mean of differences was positive (0.34). Such results confirm the findings of Felippe (5), who observed that measurements of $\mathrm{pH}$ of water in contact with $\mathrm{CH}$-filled teeth remained high for long periods. In that study, changing the paste caused disturbance in ion diffusion. Statistical analysis did not show significant difference between results for Groups 1, 3 and 4. However, there was a statistically significant difference in results between Groups 2 and 3.

Within the limitations of this in vitro study, $\mathrm{CH}$ paste replenishment should be avoided. In addition, if replenishing is inevitable, irrigation with $1 \% \mathrm{NaOCl}$ alone has shown to be effective in removing the $\mathrm{CH}$ paste mixed with propylene glycol.

TABLE 2- Differences in $\mathrm{pH}$ measurement between periods (30 and 60 days) for each group

\begin{tabular}{lllll}
\hline TOOTH & GROUP 1 & GROUP 2 & GROUP 3 & GROUP 4 \\
\hline 1 & -0.10 & -1.3 & 0.42 & 0.10 \\
2 & -0.81 & -0.28 & 0.29 & 0.08 \\
3 & -0.06 & -0.21 & 0.35 & 0.23 \\
4 & 1.37 & -0.23 & 0.35 & 0.13 \\
5 & -0.22 & -0.32 & 0.75 & -24 \\
6 & 0.23 & 0.06 & 0.17 & - \\
7 & -0.16 & -0.22 & 0.03 & - \\
9 & 0.10 & -0.02 & 0.14 & - \\
10 & -0.16 & 0.00 & 0.07 & - \\
\hline MEAN & 0.10 & -0.16 & 0.84 & 0.16 \\
\hline
\end{tabular}

ANOVA - $F=4.97 \quad p=0.0055$

Negative sign indicates lower $\mathrm{pH}$ at 60 days than at 30 days.

No sign indicates higher $\mathrm{pH}$ at 60 days than at 30 days.

TABLE 3- Individual comparisons using Scheffeé's test $(p<0.01)$

\begin{tabular}{ll|l}
\hline GROUP & MEAN \\
\hline 3 (no changes) & 0.34 & \\
4 (control) & 0.16 & \\
1 (EDTA + NaOCl) & 0.03 & \\
2 (NaOCl) & -0.27 & $\mid$ \\
\hline
\end{tabular}

OBS. Vertical bars indicate statistical equivalence.

\section{REFERENCES}

1- Byström A, Claesson R, Sundqvist G. The antibacterial effect of camphorated paramonochlorophenol, camphorated phenol and calcium hydroxide in the treatment of infected root canals. Endod Dent Traumatol. 1985;1:170-5.

2- Çalt S, Serper A. Dentinal tubule penetration of root canal sealers after root canal dressing with calcium hydroxide. J Endod. 1999;25:431-3.

3- Deardorf KA, Swartz ML, Newton CW, Brown Jr CE. Effect of root canal treatments on dentin permeability. J Endod. 1994;20:1-5. 
4- Esberard RM, Carnes Jr. DL, Del Rio CE. Changes in $\mathrm{pH}$ at the dentin surface in roots obturated with calcium hydroxide pastes. J Endod. 1996;22:402-5.

5- Felippe MCS. Estudo in vitro do transporte de íons hidroxila e cálcio através da dentina radicular. Florianópolis; 1998. [Dissertação de Mestrado - Faculdade de Odontologia da UFSC].

6- Fogel HM, Marshall FJ, Pashley DH. Effects of distance from the pulp and thickness on the hydraulic conductance of human radicular dentin. J Dent Res. 1988;67:1381-5.

7- Foster KH, Kulild JC, Weller RN. Effect of smear layer removal on the diffusion of calcium hydroxide through radicular dentin. J Endod. 1993;19:136-40.

8- Hermann BW. Dentinobliteration der wurzel kanale nach. Behandlung mit calcium. Zahnartzl Resch. 1920;39:888.

9- Hudson DA, Remeikis NA, Van Cura JE. Instrumentation of curved root canals: a comparison study. J Endod. 1992;18:448-50.

10- Lambrianidis T, Margelos J, Beltes P. Removal efficiency of calcium hydroxide dressing from the root canal. J Endod. 1999;25:858 .

11- Nerwich A, Figdor D, Messer HH. pH changes in root dentin over a 4-week period following root canal dressing with calcium hydroxide. J Endod. 1993;19:302-6.

12- Pashley DH, Kalathoor S, Burnham D. The effects of calcium hydroxide on dentin permeability. J Dent Res. 1986;65:417-20.

13- Porkaew P, Retief DH, Barfield RD, Lacefield WR, Soong S. Effects of calcium hydroxide paste as an intracanal medicament on apical seal. J Endod. 1990;16:369-74.

14- Reeder Jr OW, Walton RE, Livingston MJ, Pashley DH. Dentin permeability: determinants of hydraulic conductance. J Dent Res. 1978;57:187-93.

15- Souza V, Bernabé PFE, Holland R, Nery MJ, Mello W, Otobon Filho JA. Tratamento não-cirúrgico de dentes com lesões periapicais. RBO. 1989;46:39-46.

16- Staehle HJ, Spiess V, Heinecke A, Müller HP. Effect of root canal filling materials containing calcium hydroxide on the alkalinity of root dentin. Endod Dent Traumatol. 1995;11:163-8.

17- Stuart KG, Miller CH, Brown Jr CE, Newton CW. The comparative antimicrobial effect of calcium hydroxide. Oral Surg Oral Med Oral Pathol. 1991;72:101-4

18- Tatsuta CT, Morgan LA, Baumgartner JC, Adey JD. Effect of calcium hydroxide and four irrigation regimens on instrumented and uninstrumented canal wall topography. J Endod. 1999;25:93-8.

19- Tronstad L. The use of calcium hydroxide in endodontic therapy. J Endod. 1976;2:356-7.

20- Tronstad L, Andreasen JO, Hasselgren G, Kristerson L, Riis I. pH changes in dental tissues after root canal filling with calcium hydroxide. J Endod. 1981;7:17-21. 